UDC 539.3

\author{
V.Yu. Miroshnikov
}

Kharkiv National University for Civil Engineering and Architecture

\title{
EVALUATION OF THE STRESS-STRAIN STATE OF HALF-SPACE WITH CYLINDRICAL CAVITIES
}

A three-dimensional problem was solved in the theory of elasticity for an elastic uniform halfspace with cylindrical cavities parallel to each another and the half-space boundary. Stresses rapidly decaying to zero at big distances from the origin of coordinates are specified on the boundaries of cylindrical cavities and on the half-space boundary.

The problem of solving such problems is topical. It is encountered in practice and solved using approximate methods. The approach used herein yields solutions of the stated problem with an a priori specified accuracy depending on the system order. In contrast to publications referred to in the paper, the focus, apart from another approach, was on analysing the stress state of half-space to study the mutual influence of cylindrical cavities and of the cavities with half-space boundary.

The problem was solved using the generalised Fourier method for Lame equations in cylindrical coordinates linked to cylinders and Cartesian coordinates linked to half-space. For transition between basic solutions of Lame's equations, special formulas were used for transition between local cylindrical systems of coordinates and between the Cartesian and cylindrical systems of coordinates. The truncation method was used to solve infinite systems of linear algebraic equations to which the problem was reduced. This yielded displacements and stresses in an elastic body. The numerical results were derived for the case of half-space and two cylinders under a load applied to the half-space boundary. Separate computations were performed for a load applied to the surface of the cylindrical cavity. In both cases the analysis of the stress-strain state indicates that space weakening due to cylindrical cavities or the half-space boundary gives rise to extremal stresses in these sites. The method can also be used for other boundary conditions. problem

Keywords: cylindrical cavities in half-space, Lame's equations, generalised Fourier method, first basic

Розв'язана тривимірна задача теорії пружності для пружного однорідного півпростору 3 циліндричними порожнинами паралельними між собою і межею півпростору. На межах циліндричних порожнин і на межі півпростору задані напруження, які швидко зменшуються до нуля на далеких відстанях від початку координат.

Проблема розрахунку таких задач с актуальною, зустрічається на практиці, де розраховусться наближеними методами. Використаний підхід дозволяє отримати розв'язок поставленої задачі 3 наперед заданою точністю, яка залежить від порядку системи. На відміну від існуючих публікацій, в даній роботі, крім іншого підходу, наголос зроблено на аналіз напруженого стану півпростору, де вивчено взаємний вплив циліндричних порожнин між собою та межею півпростору.

Розв'язок задачі отримано узагальненим методом Фур'є стосовно системи рівнянь Ламе в циліндричних координатах, пов'язаних із циліндрами, та декартових координатах, пов'язаних 3 півпростором. Для переходу між базисними розв'язками рівняння Ламе були використані особливі формули переходу між локальними циліндричними системами координат та між декартовою і циліндричними системами координат. Нескінченні системи лінійних алгебраїчних рівнянь, до яких зведено проблему, вирішено методом усічення. У результаті було знайдено переміщення та напруження в пружному тілі. Числові результати розраховано для випадку півпростору та двох циліндрів від дії навантаження, прикладеного на межу півпростору, а також окремо розраховано від дії навантаження, прикладеного на поверхні циліндричної порожнини. Аналіз напружено - деформованого стану в обох випадках свідчить про те, що послаблення простору за рахунок циліндричних порожнин, або за рахунок межі півпростору веде до появи в цих місцях екстремальних напружень. Метод може також бути застосовано для інших крайових умов.

Ключові слова: циліндричні порожнини в півпросторі, рівняння Ламе, узагальнений метод Фур'є, перша основна задача.

(C) Мірошніков В. Ю., 2018 
Получено решение трехмерной задачи теории упругости для упругого однородного полупространства с цилиндрическими полостями, параллельными между собой и границей полупространства. На границах цилиндрических полостей и на границе полупространства заданы напряжения, быстро убывающие к нулю на дальних расстояниях от начала координат.

Проблема расчета таких задач является актуальной, встречается на практике, где рассчитывается приближенными методами. Использованный подход позволяет получить решение поставленной задачи с заранее заданной точностью, которая зависит от порядка системы. В отличие от существующих публикаций, в данной работе, помимо иного подхода, упор сделан на анализ напряженного состояния полупространства, где изучено взаимное влияние цилиндрических полостей между собой и границей полупространства.

Решение задачи получено обобщенным методом Фурье относительно системы уравнений Ламе в цилиндрических координатах, связанных с цилиндрами, и декартовых координатах, связанных с полупространством. Для перехода между базисными решениями уравнения Ламе были использованы особые формулы перехода между локальными цилиндрическими системами координат, а также между декартовой и цилиндрическими системами координат. Бесконечные системы линейных алгебраических уравнений, к которым сведена проблема, решены методом усечения. В результате были найдены перемешения и напряжения в упругом теле. Численные результаты получены для случая полупространства и двух цилиндров от действия нагрузки, приложенной на границу полупространства, а также от действия нагрузки, приложенной на поверхности цилиндрической полости. Анализ напряженно-деформированного состояния в обоих случаях свидетельствует о том, что ослабление пространства за счет цилиндрических полостей, либо за счет границы полупространства ведет к появлению в этих местах экстремальных напряжений. Этот метод может также быть применен для других граничных условий.

Ключевые слова: цилиндрические полости в полупространстве, уравнения Ламе, обобщенный метод Фурье, первая основная задача.

Introduction. Design of different kinds of constructions and underground utility systems requires the knowledge of the stress-strain state of half-space with cavities and loads specified on the boundaries of cavities and half-space. This information is obtained by solving the relevant elasticity theory problem.

The approach to solving the problem stated in the title is based on the generalised Fourier method [2]. This method is used to solve the first basic elasticity theory problem for space with round cylindrical cavities [1], the mixed problem for space with cylindrical cavities when displacements are specified on the boundaries of some parallel cylindrical cavities; on others, stresses; and on other ones, tangential forces and normal displacements [9]. Studies [3-6, 8] also use the generalised Fourier method for transverse-isotropic bodies bounded by coordinate surfaces in cylindrical and paraboloid coordinates with a lumped force applied to the half-space boundary with a lumped force. Paper [7] considers the first basic elasticity theory problem for half-space with one cylindrical cavity and extremely partial conditions on the half-space boundary $\sigma_{y}=f(x) \cdot \cos (\lambda z), \tau_{y x}=\tau_{y z}=0$.

Objective of the paper. Analysis of the stress-strain state for half-space with several cylindrical cavities parallel to each another and the half-space boundary, and studying their mutual influence. The generalised Fourier method is used to achieve this goal. The problem is being considered for the first time.

Problem statement. Let us consider an elastic uniform half-space with $N$ round cylindrical parallel cavities, nonintersecting with each another and the half-space boundary. The cavities will be considered in the local cylindrical coordinate system $\left(\rho_{p}, \varphi_{p}, z\right)$, where $p$ is cylinder number, and the half-space is in the Cartesian system of coordinates $(x, y, z)$ oriented identically and linked to the system of coordinates of the cylinder with number $p=1$. The half-space boundary is located at the distance $y=h$. The 
boundary equation of half-space $S_{d}$ is $y=h$, and that of the surfaces of cylinders $S_{p}$ is $\rho_{p}=R_{p}$. Stresses are specified on the half-space boundary and on the boundaries of cavities. They will be considered rapidly decaying to zero at big distances from the origin of coordinates. It is required to find the solution of the Lame's equation $\Delta \vec{u}+(1-2 \sigma)^{-1} \nabla \operatorname{div} \vec{u}=0$ with stresses specified on the boundaries of cylindrical cavities $\vec{f}_{p}\left(\varphi_{p}, z\right), \quad p=1,2, \ldots, N ;\left(\rho_{p}, \varphi_{p}, z\right)$ is a system of local cylindrical coordinates with stress $\vec{f}_{d}(x, z)$ specified on the half-space boundary. Vectors $\vec{f}_{p}\left(\varphi_{p}, z\right)$ and $\vec{f}_{d}(x, z)$ will be assumed rapidly decaying to zero over coordinates $z$ and $x$ at big distances from the origin of coordinates.

Solution method. In the given systems of coordinates we take basic solutions of the Lame's equation:

$$
\begin{gathered}
\vec{u}_{k}^{ \pm}\left(M_{d} ; \lambda, \mu\right)=N_{k}^{(d)} u^{ \pm}\left(M_{d} ; \lambda, \mu\right), \quad(k=1,2,3), \\
\vec{R}_{k, m}\left(M_{p} ; \lambda\right)=N_{k}^{(p)} I_{m}(\lambda \rho) e^{i(\lambda z+m \varphi)},(k=1,2,3), \\
\vec{S}_{k, m}\left(M_{p} ; \lambda\right)=N_{k}^{(p)}\left[S_{m}\left(\rho_{p} ; \lambda\right) e^{i(\lambda z+m \varphi)}\right](k=1,2,3), \\
N_{1}^{(d)}=\frac{1}{\lambda} \nabla, N_{2}^{(d)}=\frac{4}{\lambda}(\sigma-1) \vec{e}_{2}^{(1)}+\frac{1}{\lambda} \nabla y, N_{3}^{(d)}=\frac{i}{\lambda} \operatorname{rot}\left(\vec{e}_{3}^{(1)}\right), \\
u^{ \pm}\left(M_{d} ; \lambda, \mu\right)=e^{i(\lambda z+\mu x) \pm \gamma y}, \\
N_{1}^{(p)}=\frac{1}{\lambda} \nabla, N_{2}^{(p)}=\frac{1}{\lambda}\left[\nabla\left(\rho \frac{\partial}{\partial \rho}\right)+4(\sigma-1)\left(\nabla-\vec{e}_{3}^{(2)} \frac{\partial}{\partial z}\right)\right], N_{3}^{(p)}=\frac{i}{\lambda} \operatorname{rot}\left(\vec{e}_{3}^{(2)}\right), \\
s_{m}\left(\rho_{p} ; \lambda\right)=(\operatorname{sign} \lambda)^{m} K_{m}\left(|\lambda| \rho_{p}\right), \gamma=\sqrt{\lambda^{2}+\mu^{2}},-\infty<\lambda, \mu<\infty,
\end{gathered}
$$

where $M_{d}=(x, y, z), M_{p}=\left(\rho_{p}, \varphi_{p}, z\right)$ are space points, respectively, in the Cartesian system of coordinates identified with the system $x_{q}, y_{q}$ (fig. 1): $x \equiv x_{q}, y \equiv y_{q}$, and in the cylindrical system of coordinates linked to the $p$-th cylinder; $\vec{e}_{j}^{(k)},(j=1,2,3)$ are unit vectors of the Cartesian $(k=1)$ and cylindrical $(k=2)$ systems of coordinates; $\sigma$ is Poisson ratio; $I_{m}(x)$ and $K_{m}(x)$ are modified Bessel functions; $\vec{R}_{k, m}, \vec{S}_{k, m},(k=1,2,3)$, respectively, are the internal and external solutions of the Lame's equation for the cylinder; $\vec{u}_{k}^{(-)}, \vec{u}_{k}^{(+)}$are solutions of the Lame's equation for half-space.

The problem solution is given in the form

$$
\vec{U}=\sum_{k=1}^{3} \int_{-\infty}^{\infty} \int_{-\infty}^{\infty} H_{k}(\lambda, \mu) \cdot \vec{u}_{k}^{(+)}\left(M_{d} ; \lambda, \mu\right) d \mu d \lambda+\sum_{p=1}^{N} \sum_{k=1}^{3} \int_{-\infty}^{\infty} \sum_{m=-\infty}^{\infty} B_{k, m}^{(p)}(\lambda) \vec{S}_{k, m}\left(M_{p} ; \lambda\right) d \lambda
$$

where $\vec{S}_{k, m}\left(M_{p} ; \lambda\right)$ and $\vec{u}_{k}^{(+)}\left(M_{d} ; \lambda, \mu\right)$ are basic solutions specified by (1) and (2), with sought for functions $H_{k}(\lambda, \mu)$ and $B_{k, m}^{(p)}(\lambda)$ being found from boundary conditions.

For transition between systems of coordinates (fig. 1) we use the next formulas. 


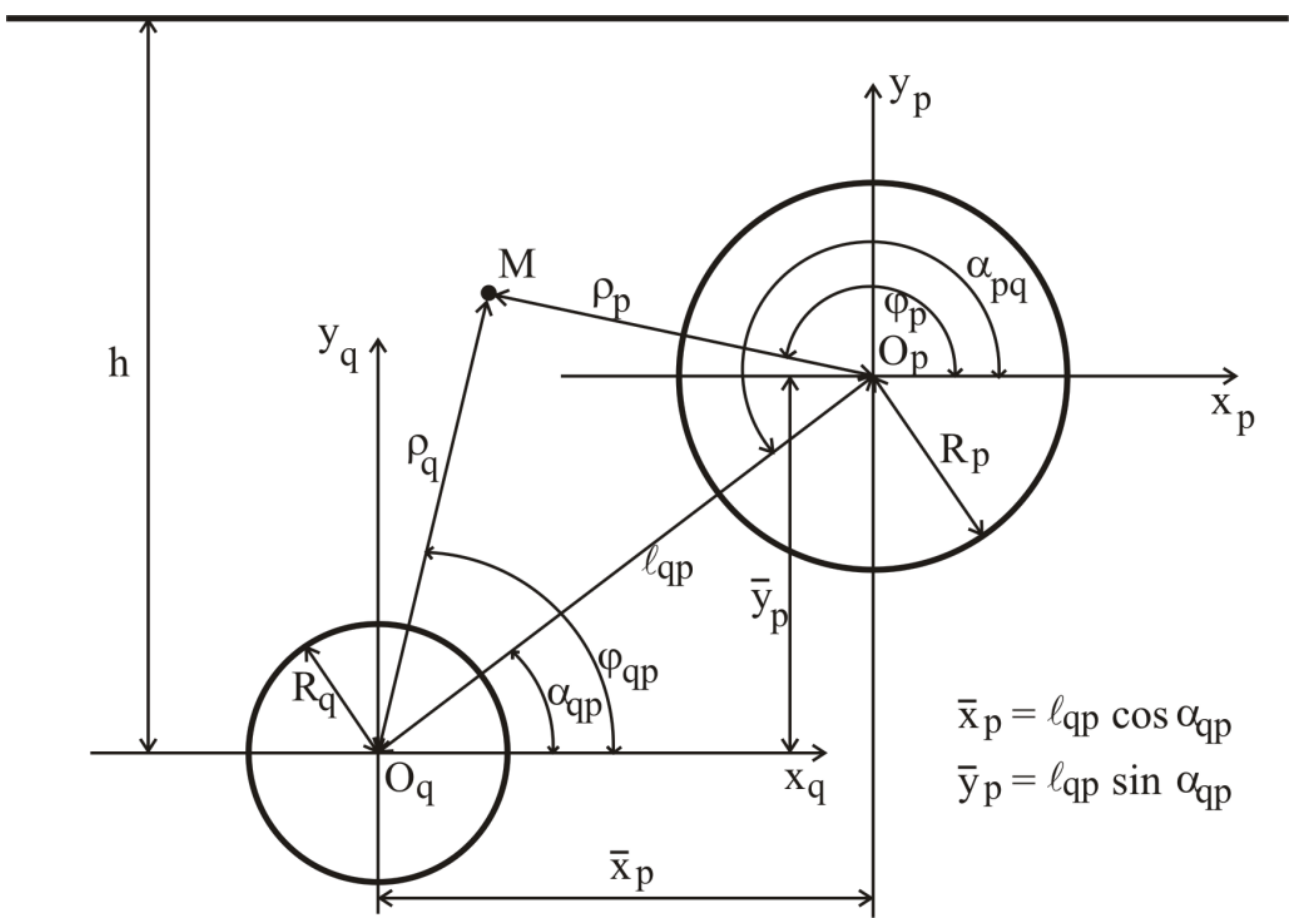

Fig. 1. Half-space with cylindrical cavities

Formulas using for transition from coordinates of cylinder with number $p$ to the half-space coordinate

$$
\begin{gathered}
\vec{S}_{k, m}\left(M_{p} ; \lambda\right)=\frac{(-i \operatorname{sign}(\lambda))^{m}}{2} \int_{-\infty}^{\infty} \omega^{m} \vec{u}_{k}^{(-)} e^{-i \mu \bar{x}_{p}+\gamma \bar{y}_{p}} \frac{1}{\gamma} d \mu, k=1,3, \\
\vec{S}_{2, m}\left(M_{p} ; \lambda\right)=\frac{(-i \operatorname{sign}(\lambda))^{m}}{2} \int_{-\infty}^{\infty} \omega^{m}\left(\left(m \mu-\frac{\lambda^{2}}{\gamma}+\lambda^{2} y_{p}\right) \vec{u}_{1}^{(-)}-\lambda^{2} \vec{u}_{2}^{(-)}+4 \mu(1-\sigma) \vec{u}_{3}^{(-)}\right) * \\
* \frac{e^{-i \mu \bar{x}_{p}+\gamma \bar{y}_{p}}}{\gamma^{2}} d \mu,
\end{gathered}
$$

where $\gamma=\sqrt{\lambda^{2}+\mu^{2}} ; \omega(\lambda, \mu)=\frac{\mu-\gamma}{\lambda} ; y>0 ; m=-\infty \ldots \infty$.

Formulas using for transition from half-space coordinates to coordinates of cylinder $p$

$$
\begin{gathered}
\vec{u}_{k}^{(+)}=\sum_{m=-\infty}^{\infty}(i \omega)^{m} \vec{R}_{k, m} e^{i \mu \bar{x}_{p}+\gamma \bar{y}_{p}}, k=1,3, \\
\vec{u}_{2}^{(+)}=e^{i \mu \bar{x}_{p}+\gamma \bar{y}_{p}} \sum_{m=-\infty}^{\infty}\left[(i \omega)^{m} \lambda^{-2}\left(m \mu \vec{R}_{1, m}+\gamma \vec{R}_{2, m}+4 \mu(1-\sigma) \vec{R}_{3, m}\right)+\bar{y}_{p}(i \omega)^{m} \vec{R}_{1, m}\right]
\end{gathered}
$$

where $\vec{R}_{k, m}=\overrightarrow{\widetilde{b}}_{k, m}\left(\rho_{p}, \lambda\right) e^{i\left(n \varphi_{p}+\lambda z\right)} ; \bar{x}_{p}, \bar{y}_{p}$ are coordinates of cylinder $p$ relative to the first cylinder;

$\overrightarrow{\widetilde{b}}_{1, n}\left(\rho_{p}, \lambda\right)=\vec{e}_{\rho} I_{n}^{\prime}\left(\lambda \rho_{p}\right)+i I_{n}\left(\lambda \rho_{p}\right)\left(\vec{e}_{\varphi} \frac{n}{\lambda \rho_{p}}+\vec{e}_{z}\right)$ 


$$
\begin{aligned}
& \overrightarrow{\widetilde{b}}_{2, n}\left(\rho_{p}, \lambda\right)=\vec{e}_{\rho}\left[(4 \sigma-3) \cdot I_{n}^{\prime}\left(\lambda \rho_{p}\right)+\lambda \rho_{p} I_{n}^{\prime \prime}\left(\lambda \rho_{p}\right)\right]+\vec{e}_{\varphi} i m\left(I_{n}^{\prime}\left(\lambda \rho_{p}\right)+\frac{4(\sigma-1)}{\lambda \rho_{p}} I_{n}\left(\lambda \rho_{p}\right)\right)+ \\
& +\vec{e}_{z} i \lambda \rho_{p} I_{n}^{\prime}\left(\lambda \rho_{p}\right) ; \\
& \overrightarrow{\widetilde{b}}_{3, n}\left(\rho_{p}, \lambda\right)=-\left[\vec{e}_{\rho} I_{n}\left(\lambda \rho_{p}\right) \frac{n}{\lambda \rho_{p}}+\vec{e}_{\varphi} i I_{n}^{\prime}\left(\lambda \rho_{p}\right)\right] .
\end{aligned}
$$

Formulas using for transition from the coordinates of cylinder with number $p$ to coordinates of cylinder $q$

$$
\vec{S}_{k, m}\left(M_{p} ; \lambda\right)=\sum_{n=-\infty}^{\infty} \vec{b}_{k, p q}^{m n}\left(\rho_{q}\right) e^{i\left(n \varphi_{q}+\lambda z\right)}, k=1,2,3,
$$

where

$$
\begin{aligned}
\vec{b}_{1, p q}^{m n}\left(\rho_{q}\right) & =(-1)^{n} \tilde{K}_{m-n}\left(\lambda \ell_{p q}\right) \cdot e^{i(m-n) \alpha_{p q}} \cdot \overrightarrow{\tilde{b}}_{1, n}\left(\rho_{q}, \lambda\right) ; \\
\vec{b}_{3, p q}^{m n}\left(\rho_{q}\right) & =(-1)^{n} \widetilde{K}_{m-n}\left(\lambda \ell_{p q}\right) \cdot e^{i(m-n) \alpha_{p q}} \cdot \overrightarrow{\tilde{b}}_{3, n}\left(\rho_{q}, \lambda\right) ; \\
\vec{b}_{2, p q}^{m n}\left(\rho_{q}\right) & =(-1)^{n}\left\{\widetilde{K}_{m-n}\left(\lambda \ell_{p q}\right) \overrightarrow{\widetilde{b}}_{2, n}\left(\rho_{q}, \lambda\right)-\frac{\lambda}{2} \ell_{p q} *\right. \\
* & {\left.\left[\widetilde{K}_{m-n+1}\left(\lambda \ell_{p q}\right)+\widetilde{K}_{m-n-1}\left(\lambda \ell_{p q}\right)\right] \overrightarrow{\widetilde{b}}_{1, n}\left(\rho_{q}, \lambda\right)\right) e^{i(m-n) \alpha_{p q}} ; }
\end{aligned}
$$

$\alpha_{p q}$ - angle between coordinate axes and section $\ell_{q p} ; \tilde{K}_{m}(x)=(\operatorname{sign}(x))^{m} \cdot K_{m}(|x|)$.

To satisfy the boundary conditions on the boundary of half-space $y=h$ we rewrite the right-hand side of (3) with transition formulas (4) to the Cartesian system of coordinates through basic solutions $\vec{u}_{k}^{( \pm)}$. For the vector derived, we find the stress and set it at $y=h$ to specified $\vec{f}_{d}(x, z)$, which first will be represented with a double Fourier integral, and designate this expression as

$$
F \vec{U}_{\mid y=h}=\vec{f}_{d}(x, z) .
$$

Using formulas for transition from the Cartesian system to the cylindrical one (5), and from one cylinder to another one (6), we write (3) in the coordinates of the cylinder with number $p$ through basic solutions $\vec{R}_{k, m}, \vec{S}_{k, m}$. If now we find stresses caused by $\vec{U}$ on the surface of cylindrical cavities and account for boundary conditions, we will find equality

$$
F \vec{U}_{\mid \rho_{p}=R_{p}}=\vec{f}_{p}\left(\varphi_{p}, z\right), p=1,2, . ., N .
$$

From (7) we find $H_{k}(\lambda, \mu)$ in terms of $B_{k, m}^{(p)}(\lambda)$ and substitute $H_{k}(\lambda, \mu)$ into (8). This yields a set of $3 N$ infinite systems of linear algebraic equations for finding unknowns $B_{k, m}^{(p)}(\lambda)$

For the systems obtained, their unique solvability can be proved. Moreover, these systems can be solved using the truncation method, with convergence of approximate solutions to an exact one. Functions $B_{s, m}^{(p)}(\lambda)$ found from the infinite system of equations are substituted into the expressions for $H_{k}(\lambda, \mu)$. This will determine all unknown problems. 
Numerical results. Let there be two parallel cylindrical cavities in half-space (fig. 1). The space is an isotropic material with the Poisson ratio $\sigma=0.35$ and elasticity module $E=2 \mathrm{kN} / \mathrm{cm}^{2}$. The half-space boundary is located at distance $h=40$, with the distance between the cylinders $\ell_{q p}=R_{p}+h, \alpha_{q p}=0$. On the boundaries of the cylinders stresses are specified as

$$
\sigma_{\rho}^{(p)}=\sigma_{\rho}^{(q)}=0, \quad \tau_{\rho \varphi}^{(p)}=\tau_{\rho \varphi}^{(q)}=0, \quad \tau_{\rho \mathrm{Z}}^{(\mathrm{p})}=\tau_{\rho \mathrm{Z}}^{(\mathrm{q})}=0,
$$

on the half-space boundary

$$
\begin{gathered}
\sigma_{y}^{(d)}=-\left(10^{4} \cdot\left(z^{2}+10^{2}\right)^{-2}\right), 0 \leq x \leq \ell_{q p}, \\
\sigma_{y}^{(d)}=0, x<0 \text { and } x>\ell_{q p}, \quad \tau_{y x}^{(d)}=\tau_{y z}^{(d)}=0 .
\end{gathered}
$$

The obtained infinite system of equations was reduced to a finite one for parameter $m$ - system order (parameter $m$ is investigated in [7]), and the integration limits for the given function for $\mu$ and $\lambda$ were set to -10 to 10 . The integrals were computed using Filon and Simpson quadrature formulas. The accuracy of satisfying the boundary conditions where they are continuous, due to these parameters, was brought to $10^{-4}$.

Fig. 2 shows the stress state of half-space for $z=0$ at different distances from the halfspace boundary $y=h$.
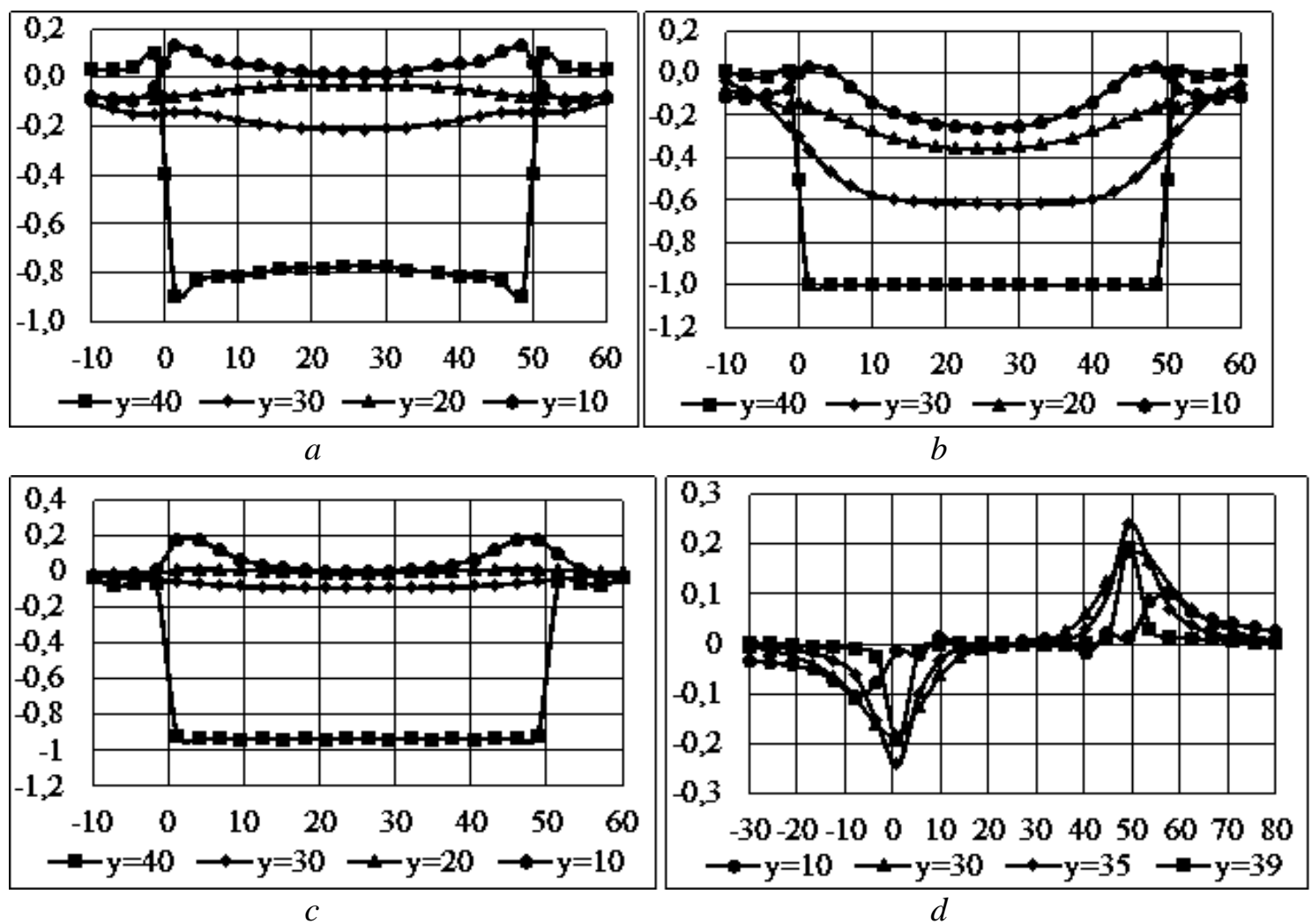

Fig. 2. Stresses in half-space with cylindrical cavities in plane $z=0$ :

$$
a-\sigma_{x} ; b-\sigma_{y} ; c-\sigma_{z} ; d-\tau_{x y}
$$


For comparison, the stress state for half-space without cylindrical cavities was computed (fig. 3).
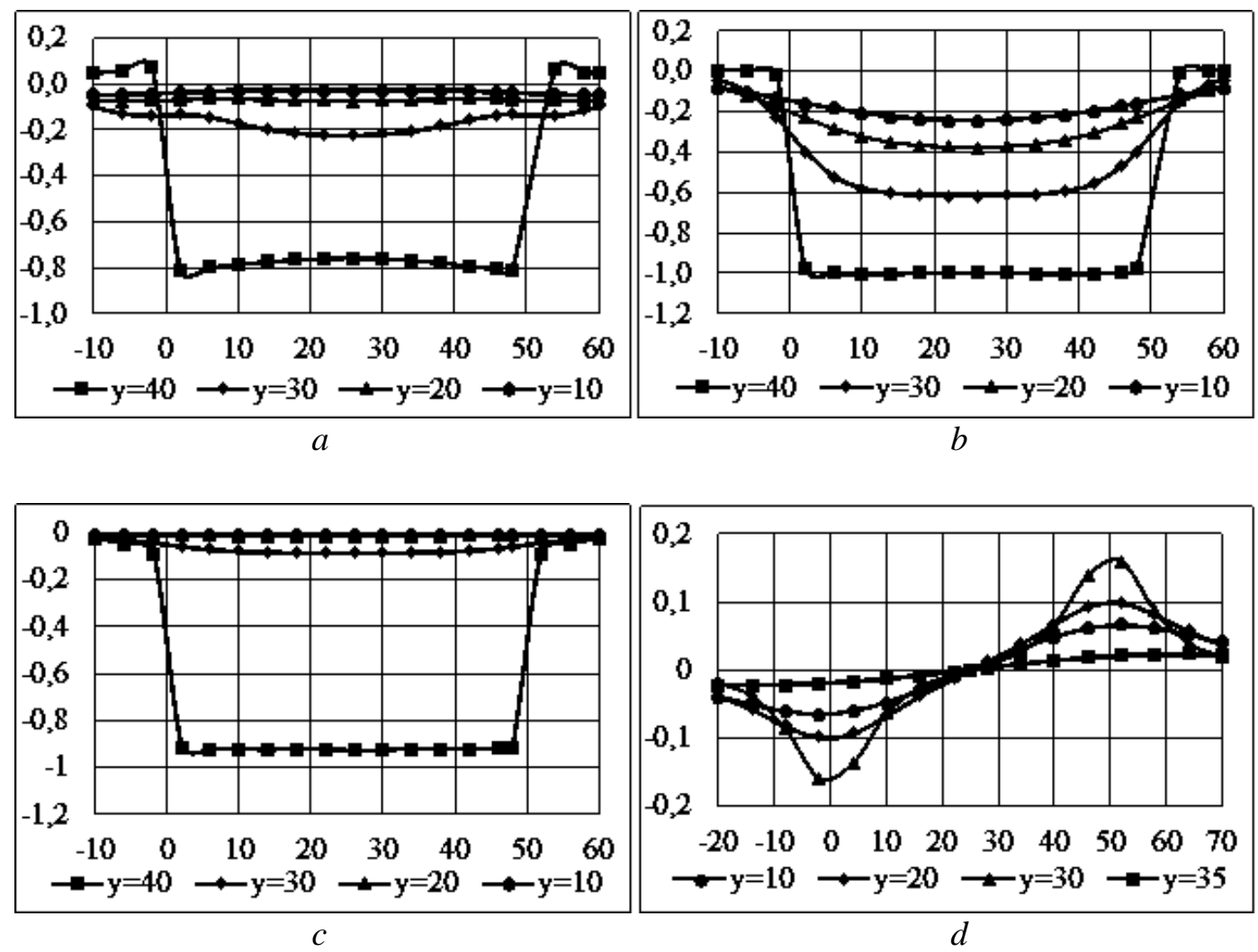

Fig. 3. Stresses in half-space without cylindrical cavities in plane $z=0$ :

$$
a-\sigma_{x} ; b-\sigma_{y} ; c-\sigma_{z} ; d-\tau_{x y}
$$

Fig. 2 shows that, in moving away from the half-space boundary, stresses $\sigma_{x}$ and $\sigma_{y}$ decrease, though, as compared to fig. 3, $a$ and fig. 3, $b$, at the level of cylinders $(y=10)$ they have another stress pattern. With cylindrical cavities in half-space, stresses $\sigma_{z}$ (fig. $2, c$ ) have extremal values near the surfaces of cylinders (at $x=0, x=50$ ), as distinct to fig. 3, $c$ where stresses decrease gradually with a bigger distance from the halfspace boundary. With weakened space, tangential forces $\tau_{x y}$ (fig. $2, d$ ) have extremal values near the surfaces of cylinders, in contrast to half-space with no cylindrical cavities where, in moving away from the boundary of half-space, $\tau_{x y}$ first rise sharply in sites where loads terminate, and then they decrease gradually.

If the half-space boundary is unloaded and the cylindrical cavity is loaded, for the next boundary conditions

$$
\begin{gathered}
\sigma_{\rho}^{(p)}=-\left(10^{4} \cdot\left(z^{2}+10^{2}\right)^{-2}\right) ; \sigma_{\rho}^{(q)}=0 ; \tau_{\rho \varphi}^{(p)}=\tau_{\rho \varphi}^{(q)}=0 ; \tau_{\rho z}^{(p)}=\tau_{\rho z}^{(q)}=0, \\
\sigma_{y}^{(d)}=0 ; \tau_{y x}^{(d)}=\tau_{y z}^{(d)}=0,
\end{gathered}
$$

we have the following grafics (fig. 4). 

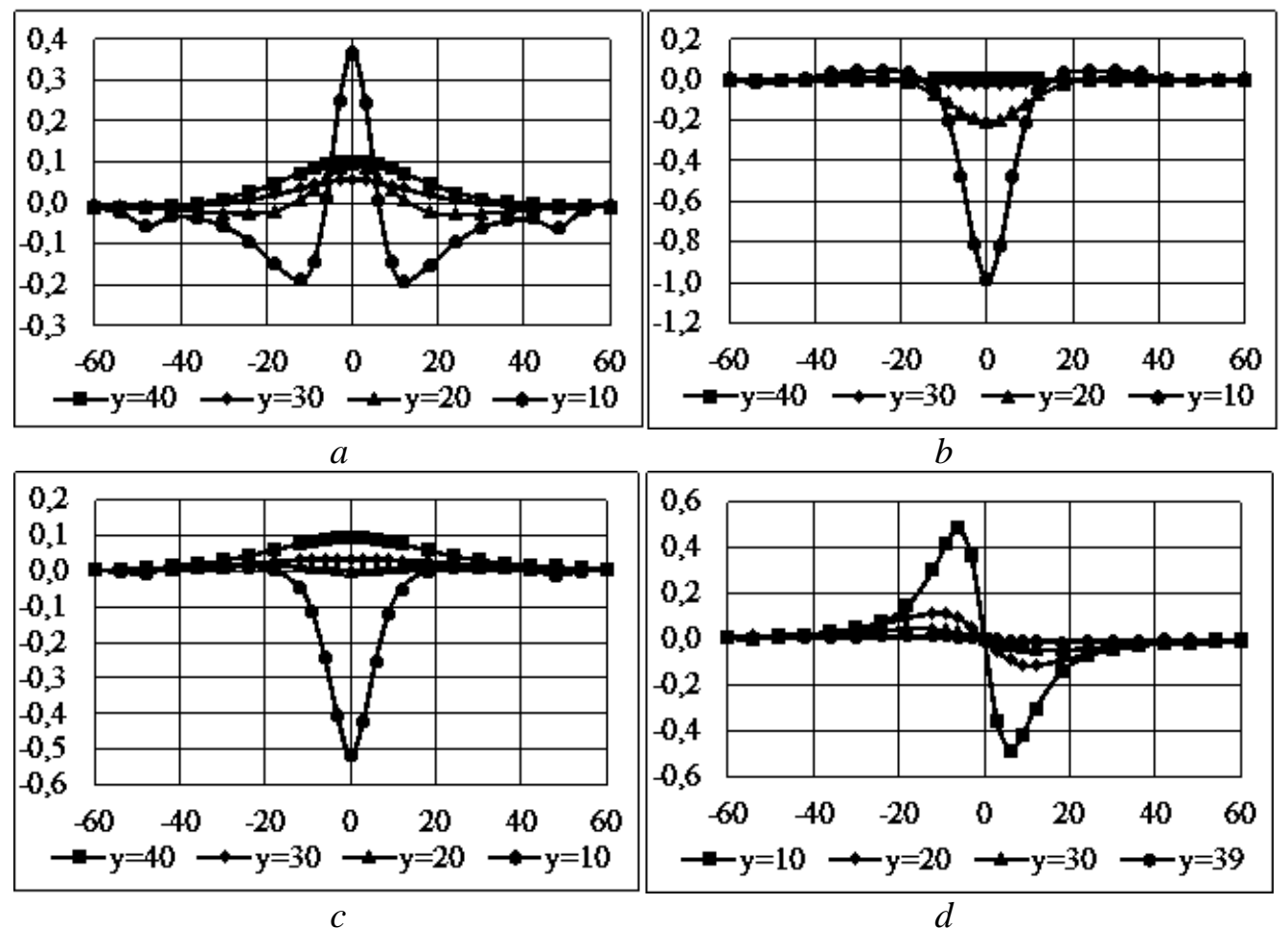

Fig. 4. Stresses in half-space with cylindrical cavities in plane $z=0$ when the half-space boundary is unloaded and the cylindrical cavity is loaded: $a-\sigma_{x} ; b-\sigma_{y} ; c-\sigma_{z} ; d-\tau_{x y}$
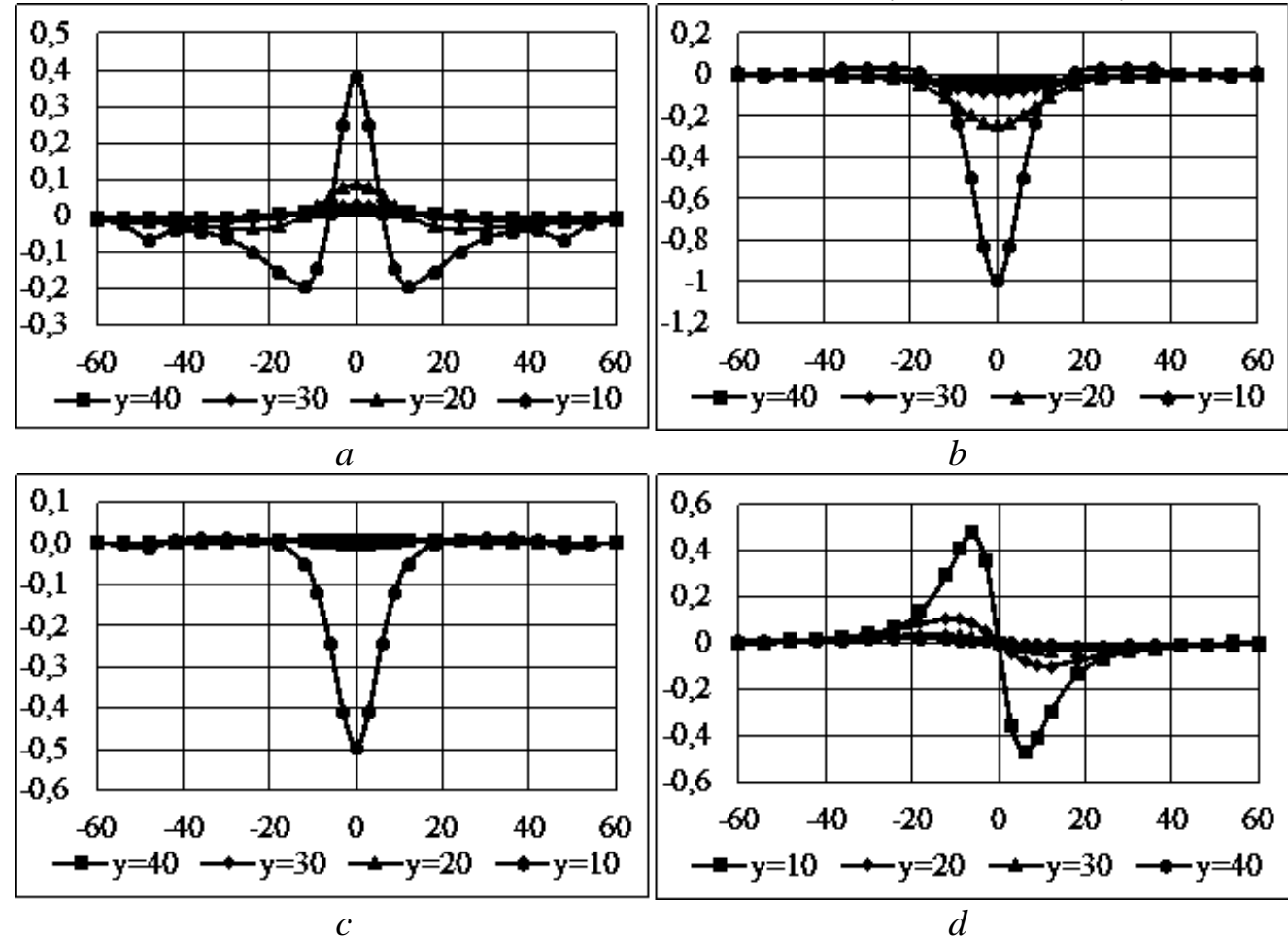

Fig. 5. Stresses in space with cylindrical cavities in plane $z=0$ when the half-space boundary is unloaded and the cylindrical cavity is loaded: $a-\sigma_{x} ; b-\sigma_{y} ; c-\sigma_{z} ; d-\tau_{x y}$ 
As compared to the stress state in space (fig. 5), $\sigma_{x}$ and $\sigma_{z}$ on the half-space boundary $(y=40)$ take non-zero values due to the influence of the half-space boundary. More over, stresses $\sigma_{x}$ and $\sigma_{z}$ on the cylinder surface $(y=10)$ are maximum. In approaching to half-space, the stresses decrease, and close to the half-space boundary, they increase.

Conclusions. The generalised Fourier method is used for solving the spatial elasticity theory problem when stresses are specified on the half-space boundary and on the boundaries of several parallel cylindrical round cavities. The problem is reduced to a set of infinite systems of linear algebraic equations. The systems can be solved using the reduction method.

Numerical analysis of the algebraic system for two cylinders in half-space demonstrates that this method enables finding its solution with any degree of accuracy. This is confirmed by the high accuracy of satisfying the boundary conditions.

The graphs show the stress patterns in half-space in the most interesting zones and the mutual influence of half-space boundaries and cavities.

\section{Bibliographic references}

1. Miroshnikov, V.Yu. The first basic problem in the theory of elasticity in space with $\mathrm{N}$ parallel round cylindrical cavities [Text] / V.Yu. Miroshnikov // Problemy Mashynostroyenia [Mechanical Engineering Problems]. Kharkiv. - 2017.- Vol. 20. - No. 4. - P. 45 - 52.

2. Nikolayev, A.G. The generalised Fourier method for spatial problems in the theory of elasticity [Text] / A.G. Nikolayev, V.S. Protsenko. -N.Ye. Zhukovskii National Aerospace University «KhAI», Kharkiv, 2011. - 344 p.

3. Nikolayev, A.G. Apparatus and applications of the generalised Fourier method for transverse-isotropic bodies bounded by a plane and a paraboloid of revolution [Text] / A.G. Nikolayev, Yu.A. Shcherbakova // Mat. Metody ta Fiz.-Mekh. Polia [Math. Methods and Phys.-Mech. of a Field]. - 2009. - Vol. 52. - No. 3. - P. 160 - 169.

4. Nikolayev, A.G. Substantiation of the Fourier method in asymmetrical problems in the theory of elasticity for transverse-isotropic bodies bounded by a paraboloid surface [Text]/ A A.G. Nikolayev, Yu.A. Shcherbakova // Open informational and computer-aided integrated technologies: Proceedings. N.Ye. Zhukovskii National Aerospace University "KhAI", Kharkiv.2010. - Iss. 48. - P. $180-190$.

5. Nikolayev, A.G. Action of a lumped force on transverse-isotropic half-space with a paraboloid containment [Text]/A A.G. Nikolayev, A.Yu. Shcherbakova, A.I. Yukhno //Design and production of aircraft constructions. Proceedings N.Ye. Zhukovskii National Aerospace University "KhAI". Kharkiv. NAKU. - 2006. - Iss. 2(45). - P. 47 - 51.

6. Nikolayev, A.G. Solution of the first axisymmetric thermal elasticity boundary value problem for a transverse-isotropic half-space with a spheroidal cavity [Text] / A.G. Nikolayev, Ye.M. Orlov // Problemy Obchysliuvalnoi Mekhaniky i Mitsnosti Konstruktsii [Computational Mechanics and Strength of Constructions]. O. Honchara Dnipropetrovsk National University. Dnipro.- 2012. - Iss. 20. - P. 253-259.

7. Protsenko, V.S. Application of the generalised Fourier method to solving the first basic problem in the theory of elasticity in half-space with a cylindrical cavity [Text] / V.S. Protsenko, N.A. Ukrainets // Visnyk Zaporizhskoho Natsional'noho Universytetu [Bull. of Zaporizhia National University]. Zaporizhia. - 2015. - Iss. 2. - P. 193 - 202.

8. Shcherbakova, Yu.A. Comparative analysis of the stress-strain state of multiplyconnected transverse-isotropic bodies with different elastic characteristics [Text]/ Yu.A. Shcherbakova, Ye.M. Shekhvatova // Visnyk Zaporizhskoho Natsional'noho Universytetu [Bull. of Zaporizhia National University]. Zaporizhia. - 2015. - Iss. 2. - P. 253 - 261. 
9. Miroshnikov, V.Yu. On computation of the stress-strain state of a space weakened by a system of parallel circular cylindrical cavities with different boundary conditions [Text] / V. Yu. Miroshnikov//4th International Conference Science and Practice: a New Level of Integration in the Modern World. Conf. Proceedings. Scope Academic House. - Sheffield, UK. 2017. - P. 77-83.

Надійшла до редколегії 27.05.2017

\author{
Anatoly P.Lukisha \\ Institute of Geotechnical Mechanics of the National Academy of Sciences of Ukraine
}

\title{
RECALCULATION METHOD OF THE CHARACTERISTICS OF STRAIGHT-FLOW TUBULAR POROUS STEAM GENERATORS FROM BOUNDARY CONDITIONS OF THE SECOND KIND FOR BOUNDARY CONDITIONS OF THE THIRD KIND
}

The article is devoted to the development of a method for recalculating the thermo-hydraulic characteristics of porous straight-through steam-generating channels from boundary conditions of the second kind to boundary conditions of the third kind. The need for the development of such recalculation procedure is due to the presence in the literature of calculated dependences describing the heat transfer during evaporation of the coolant in porous channel for boundary conditions of the second kind, while the practical plan problems are often conditioned by other boundary conditions, in particular boundary conditions of the third kind. The ultimate goal of the recalculation method was to create a program for calculating the thermo-hydraulic efficiency of porous straight-through steam generators. The proposed recalculation technique makes it possible to calculate, in the porous straightthrough steam generators, for boundary conditions of the third kind, such thermal-hydraulic characteristics as the length of the channel required for complete evaporation of the heat carrier; the power required to pumping the coolant in this case, and the total amount of heat transferred to the heat carrier during evaporation. To describe the calculation of the heat transfer during the evaporation of two-phase flows in porous materials, the experimental dependence obtained by I.V. Kalmykov, characterizing the intensity of volumetric intraporous heat exchange, depending on the regime parameters of the flow, was used. This universal experimental dependence is suitable for various types of porous materials. For calculating the hydraulic characteristics of a evaporating two-phase vaporliquid flow in a porous high thermo-conducting material was used adapted by Yu.A. Zeygarnik and I.V. Kalmykov experimental dependence that was founded on the Lockhart-Martinelli method for calculating the hydro-resistance of vapor-gas flows in porous media. The technique presented in the article makes it possible to calculate the thermal-hydraulic characteristics of porous straight-flow porous steam generators for boundary conditions of the third kind.

Keywords: porous straight-through steam generators, recalculation of thermo-hydraulic characteristics from boundary conditions of the second kind to boundary conditions of the third kind.

Стаття присвячена розробці методу перерахунку теплогідравлічних характеристик пористих прямоточних парогенеруючих каналів з граничних умов другого роду для граничних умов третього роду. Необхідність розробки даної методики обумовлена наявністю в літературі розрахункових залежностей, що описують теплообмін при випаровуванні теплоносія в порстих каналах для граничних умов другого роду, в той час, як завдання практичного плану часто обумовлені іншими граничними умовами, зокрема, граничними умовами третього роду. Остаточною метою методики перерахунку було створення програми по обчисленню теплогідравлічної ефективності пористих прямоточних парогенераторів. Запропонована методика перерахунку дозволяс обчислювати в прямоточних пористих парогенераторах для

(C) Lukisha Anatoly P., 2018 